\title{
Jaminan Sosial Tenaga kerja Bagi Mahasiswa Magang Profesi Pada Perguruan Tinggi Implementasi dari Undang-Undang Ketenagakerjaan
}

\author{
Ronny Soplantila \\ Fakultas Hukum Universitas Pattimura, Ambon, Indonesia \\ E-mail: ronnysoplantila@gmail.com
}

\begin{abstract}
Higher education will send final semester students to internships in government agencies and private companies to provide experience before entering the workforce, but in practice never pay attention to the form of protection for students, while the labor law provides space for student interns to enter into workforce social security program, for this purpose the purpose of this study is to examine whether student internships can be equated with workers and are entitled to workforce protection. Guaranteed labor protection for intern students is very important both for intern students, universities and government agencies and private companies. Because it will protect students, comfort for family students and universities will feel free from moral burdens in the event of work accidents in government agencies and private companies where the student is placed.
\end{abstract}

Keywords: Student Internship; Social security protection; implementation.

\section{A. PENDAHULUAN}

Setiap tahunnya hampi seluruh perguruan tinggi di Indonesia akan mengirimkan mahasiswanya untuk mengikuti proses magang pada instansi pemerintah maupun perusahaan swasta, pada umumnya hal ini dilakukan guna untuk memperbiasakan mahasiswa dengan dunia kerja dan budaya kerja yang akan dimasuki pasca lulus dari perguruan tinggi. Selain itu magang juga bertujuan untuk membangun jaringan antara dunia pekerjaan dengan perguruan tinggi. Umumnya fakultas yang memberikan program magang profesi dalam bentuk KKN profesi adalah Fakultas Hukum, Fakultas Teknik, Fakultas Pertanian dan FKIP.

Dalam prakteknya pengelolaan mahasiswa untuk mengikuti proses magang ini hanya difokuskan pada hal yang berkaitan dengan hal yang sifatnya akademis, misalnya persiapan untuk pengenalan dunia kerja yang dilakukan sebelum mengikuti proses magang, yang biasa dikenal dengan proses pembekalan. Ada hal lain yang tak kalah pentingnya namun tidak terlalu diperhatikan, yaitu jaminan sosial tenaga kerja. Hal ini dapat terjadi karena pemahaman mengenai jaminan sosial tenaga kerja selama ini hanya berlaku dalam dunia pekerjaan. 
Bila melihat dari pentingnya jaminan sosial tenaga kerja, dalam proses magang profesi perguruan tinggi dirasa perlu memerhatikan hal ini, karena dalam pekerjaan apapun akan ada resiko kecelakaan kerja, Pengertian kecelakan kerja itu sendiri dalam Undang - Undang No. 40. Tentang Sistem Jaminan Sosial Nasional adalah kecelakaan yang terjadi dalam hubungan kerja, termasuk kecelakaan yang terjadi dalam perjalanan dari rumah menuju tempat kerja atau sebaliknya, dan penyakit yang disebabkan oleh lingkungan kerja ${ }^{1}$. Jaminan sosial adalah suatu kebijakan publik dengan demikian harus jelas tujuan yang ingin dicapai, ${ }^{2}$ sebagai akibat kelemahan pemerintah dalam pengimplementasikan undang-undang, bahkan cendrung terjadi penyimpangan, termasuk permasalahan koordinasi dan kenerja antar lembaga yang belum optimal. ${ }^{3}$

Dengan diimlementasikannya jaminan sosial tenaga kerja dalam proses magang profesi dirasa akan memiliki dampak yang sangan baik bagi, mahasiswa, orang tuanya, pihak fakultas dan universitas itu sendiri. Dampak untuk mahasiswa itu sendiri akan dirasakan dalam bentuk perlindungan yang dijaminkan oleh badan penyelenggara jaminan sosial selama menjalankan proses magang. Sementara untuk orang tua akan merasa nyaman dengan kondisi anaknya yang sudah terlindungi, untuk pihak fakultas dan universitas juga akan terlepas dari beban secara moral apabila terjadi kecelakaan kerja dalam proses magang profesi, selain itu hal ini juga akan berdampak pada instransi pemerintah dan perusahaan swasta yang bekerjasama dengan universitas.

Masalah yang sering timbul dalam proses peningkatan perlindungan jaminan sosial tenaga kerja adalah finansial, jika usaha peningkatan perlindungan jaminan sosial tenaga kerja berimlikasi pada peningkatan biaya produksi maka majikan hanya berkenan menerima tanggung jawab atas kecelakaan kerja dengan segala akibat terbatas, yaitu hanya dalam kecelakaan yang terjadi semata - mata karena kesalahan dan kelalaian dari pihak majikan sendiri ${ }^{4}$. Sama halnya dengan permasalahan yang akan dihadapi oleh universitas dalam mengimplementasian jaminan sosial tenaga kerja sebagai bentuk perlindungan bagi mahasiswa magang perguruan tinggi. dan oleh karenanya penulis merasa perlu untuk membahas dan mengkaji tentang bagaimana bentuk pengimplementasian perlindungan jaminan sosial tenaga kerja bagi mahasiswa magang pada perguruan tinggi.

\section{B. PEMBAHASAN}

\section{Konsep Mahasiswa Sebagai Tenaga Kerja}

Pengertian hukum ketenagakerjaan itu sendiri adalah hukum yang mengatur tentang tenaga kerja ${ }^{5}$. Pengertian tenaga kerja dalam Pasal 1 angka (2) adalah setiap orang yang mampu melakukan pekerjaan guna menghasilkan barang dan/atau jasa baik untuk memenuhi kebutuhan sendiri maupun untuk masyarakat.

Tenaga kerja juga dapat diartikan sebagai setiap orang, baik laki - laki atau permpuan, yang sedang dalam dan/atau akan melakukan pekerjaan baik didalam maupun

\footnotetext{
1 Pasal 1 (14) Undang - Undang No. 40 Tahun 2004 Tentang Sistem Jaminan Sosial Nasional

2 Adillah, Siti Ummu dan Anik, Sri. (2015), Kebijakan Jaminan Sosial Tenaga Kerja Sektor Informal Berbasis Keadilan Sosial Untuk Meningkatkan Kesejahteraan, Yustisia. Vol. 4 No. 3, h.559.

${ }^{3}$ Kahfi, Ashabul. (2016), Perlindungan Hukum Terhadap Tenaga Kerja, Jurisprudentie, Volume 3 Nomor 2, h. 63.

4 Uwiyono, Aloysius. (2018), Asas - Asas Hukum Perburuhan, Jakarta: Rajawali Pers, h. 126.

5 Wijayanti, Asri. (2014), Hukum Ketenagakerjaan Pasca Reformasi Cetakan ke 4, Jakarta: Sinar Grafika, h. 2 .
} 
diluar hubungan kerja guna menghasilkan barang dan/atau jasa untuk memenuhi kebutuhan sendiri atau masyarakat ${ }^{6}$. Berdasarkan penjelasan ini dapat dilihat bahwa pengertian tenaga kerja lebih luas dari pekerja/buruh, atau pekerja/buruh termasuk didalam pengertian tenaga kerja.

Berdasarkan ruang lingkup pengertian tenaga kerja yang telah dijelaskan maka dengan demikian hal ini juga dapat menjadi dasar bagi mahasiswa magang untuk dapat dikategorikan sebagai tenaga kerja, karena mahasiswa magang sudah dapat dikatakan mampu melakukan pekerjaan dan sudah dibekali pendidikan dasar di perguruan tinggi tempat dirinya menimba ilmu pengetahuan. Pada umumnya pemagangan dilakukan guna untuk memperbiasakan mahasiswa dengan dunia kerja dan budaya kerja yang akan dimasuki setelah lulus dari perguruan tinggi. Selain itu magang juga bertujuan untuk membangun jaringan antara dunia pekerjaan dengan perguruan tinggi.

Pemagangan sendiri tidak asing dalam Undang - Undang Ketenagakerjaan dimana dalam Pasal 1 Angka (11) Menyebutkan Pemagangan adalah bagian dari sistem pelatihan kerja yang diselenggarakan secara terpadu antara pelatihan di lembaga pelatihan dengan bekerja secara langsung di bawah bimbingan dan pengawasan instruktur atau pekerja/buruh yang lebih berpengalaman, dalam proses produksi barang dan/atau jasa di perusahaan, dalam rangka menguasai keterampilan atau keahlian tertentu. Namun pemagangan yang dimaksud selama hanya difokuskan bagi pekerja formal dan belum mencakup ruang lingkup mahasiswa magang.

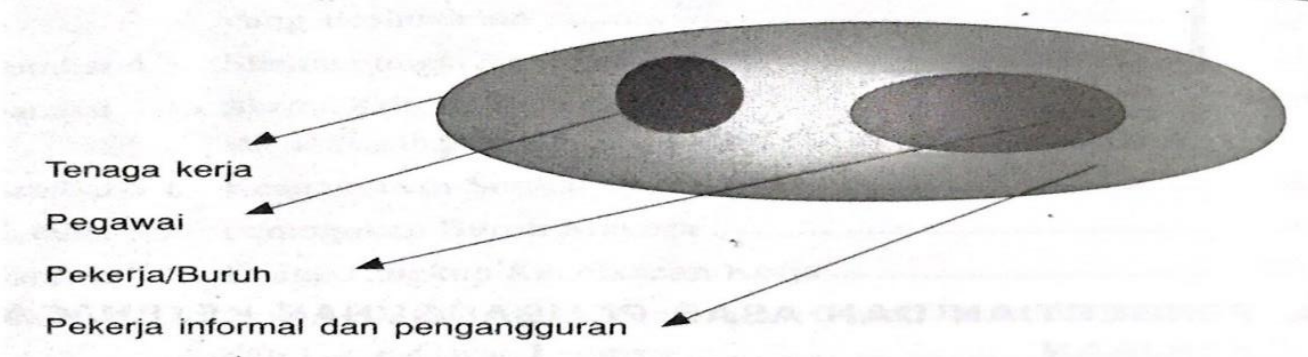

Gambar : 1.1 Batasan instilah tenaga kerja, pekerja, pegawai, dan pekerja informal serta pengangguran. ${ }^{7}$

Hukum ketenagakerjaan dahulu disebut perburuhan yang merupakan terjemahan dari arbeidsrechts. Molenaar memberikan batasan pengertian dari arbeidsrechts adalah bagian dari hukum yang berlaku pada pokoknya mengatur antara hubungan antara buruh dengan majikan, antara buruh dengan buruh dan antara buruh dengan penguasa. ${ }^{8}$ Berdasarkan pengertian ini dapat dilihat bahwa hubungan kerja merupakan hal yang penting dalam arbeidsrechts. Hal ini dikuatkan dengan pendapat Mr. MG Levenbach yang mengartikan arbeidsrechts sebagai sesuatu yang meliputi hukum yang berkenan dengan hubungan kerja. ${ }^{9}$

\footnotetext{
${ }^{6}$ Aloysius, Op. Cit. h. 32

7 Gambaran pengertian tenaga kerja menurut Asri Wijayanti

8 Soepomo, Iman. (1985), Pengantar Hukum Perburuhan, Jakarta: Djambatan, h. 1.

9 Ibid. h. 2
} 


\section{Hubungan Kerja Antara Mahasiswa, Perguruan Tinggi Dan Instansi Pemerintah Maupun Swasta}

Berdasarkan ketentuan Pasal 1 angka 15 Undang - Undang Nomor 13 tahun 2003 Tentang Ketenagakerjaan, hubungan kerja adalah hubungan antara pengusaha dan pekerja/atau buruh berdasarkan perjanjian kerja yang mempunyai unsur pekerjaan, upah, dan perintah. Selain itu ditegaskan dalam Pasal 50 Undang - Undang 13 tahun 2003 Tentang ketenagakerjaan menyebutkan hubungan kerja terjadi karena adanya perjanjian kerja antara pengusaha dan pekerja/buruh.

Perjanjian kerja merupakan faktor penting dalam hubungan kerja, sebab dalam hubungan kerja diatur mengenai hak - hak dan kewajiaban para pihak, dalam hal ini perusahaan dan pekerja. Dengan adanya perjanjian kerja perusahaan dan pekerja terikat oleh aturan - aturan yang harus dipenuhi dan ditaati sehingga hal tersebut dapat meminimalisasi masing - masing pihak mencurangi pihak lainnya, yang tentunya dapat mengakibatkan kerugian bagi salah satu pihak ${ }^{10}$

Unsur - unsur perjanjian kerja yang menjadi dasar hubungan kerja sesuai dengan ketentuan Pasal 1 angka (15) Undang - Undang Nomor 13 Tahun 2003 Tentang Ketenagakerjaan adalah :

1) Adanya Pekerjaan (Arbeid)

2) Dibawah perintah (Gezag Ver Houding)

3) Adanya upah tertentu (Loan)

Adanya Pekerjaan (Arbeid) berarti pekerjaan itu bebas sesuai dengan kesepakatan antara pekerja dan pemberi kerja asalkan tidak bertentangan dengan peraturan perundang - undangan, keusilaan, dan ketertiban umum. Dibawah perintah (Gezag Ver Houding) berarti pemberi kerja berhak dan berkewajiban untuk memberikan perintah yang berkaitan dengan pekerjaannya. Adanya upah tertentu (Loan) berarti imbalan atas pekerjaan yang telah dilakukan oleh pekerja.

Selain itu dalam Undang - Undang No. 13 Tahun 2003 Tentang Ketenagakerjaan mengenal jenis perjanjian kerja dalam bentuk perjanjian penyerahan pelaksanaan pekerjaan pada perusahaan lain. Kegiatan ini sering dikenal dengan istilah Outsourcing. Pengertian Outsourcing ini sendiri adalah pendelegasian operasi dan menejemen harian dari suatu proses bisnis ke pada pihak luar ( Perusahaan penyedia jasa Outsourcing) ${ }^{11}$.

Jenis perjanjian penyerahan pelaksanaan inilah yang dirasa cocok untuk diterapkan dalam konsep hubungan kerja antara mahasiswa perguruan tinggi dan instansi pemerintah lainnya maupun perusahaan swasta. Mahasiswa dapat diposisikan sebagai pekerja dalam hal ini, perguruan tinggi sebagai penyedia jasa ousourcing dan instansi pemerintah atau perusahaan swasta pengguna jasa sebagai pemberi kerja karena menurut hemat penulis seluruh unsur dalam perjanjian kerja telah dipenuhi mulai dari adanya pekerjaan, perintah, dan upah. Unsur pekerjaan dan perintah dirasa sudah cukup jelas penjelasannya, hanya saja upah atau imbalan yang diterima mahasiswa tidak berupa uang, namun pengalaman untuk memasuki dunia pekerjaan dan suasana pekerjaan dimana nantinya sangat akan berguna bagi mahasiswa itu sendiri dikemudian hari. Selain itu, upah atau imbalan untuk mahasiswa juga dapat dikategorikan sebagai pengabdian kepada masyarakat.

10 Sembiring, Jimmy J. (2016), Hak dan Kewajiban pekerja Berdasarkan Peraturan Terbaru Cetakan Pertama, Jakarta: Visimedia, h. 2.

11 Suwondo, Candra. (2004), Outsourcing, Implementasi Di Indonesia, Jakarta: Gramedia, h. 2. 


\section{Jaminan Sosial Tenaga Kerja Bagi Mahasiswa Magang}

Penyelenggara jaminan sosial di Indonesia secara garis besar diatur dalam Undang - Undang Nomor 40 Tahun 2004 Tentang Sistem Jaminan Sosial Nasional. Undang Undang ini menjadi payung bagi pelaksanaan jaminan sosial di Indonesia, dalam Pasal 5 (3) disebutkan bahwa ada 4 penyelenggara Arsuransi Sosial diperbolehkan beroperasi yang pelayanannya meliputi beberapa kelompok masyarakat yang masing - masing diatur oleh peraturan perundang - undangan. Diantarnya:

a) Perusahaan Perseroan (Persero) Jaminan Sosial Tenaga Kerja (JAMSOSTEK)

b) Perusahaan Perseroan (Persero) Dana Tabungan dan Arsuransi Pegawai Negeri (TASPEN)

c) Perusahaan Perseroan (Persero) Arsuransi sosial Angkatan Bersenjata Republik Indonesia (ASABRI) ; dan

d) Perusahaan Perseroan (Persero) Arsuransi Kesehatan Indonesia (ASKES).

Selain itu dalam pasal 99 Undang - Undang No. 13 Tahun 2003 juga menjadi landasan hukum bagi jaminan sosial tenaga kerja disebutkan bahwa setiap pekerja berhak untuk memperoleh jaminan sosial tenaga kerja. Tujuan diselenggarakan jaminan sosial adalah untuk memberikan kepastian perlindungan dan kesejahtaran bagi seluruh rakyat ${ }^{12}$.

Penyelenggara jaminan sosial tenaga kerja dimulai dari PT. Jamsostek, Kemudian dengan diundangkannya Undang - Undang No. 24 Tahun 2011 tentang Badan Penyelenggara Jaminan Sosial, maka terbentuklah BPJS Ketenagakerjaan dan BPJS Kesehatan, BPJS Ketenagakerjaan menyelenggarakan program jaminan kecelakaan kerja, program jaminan kematian, program jaminan hari tua dan program jaminan pensiun, BPJS Kesehatan menyelenggarakan program jaminan kesehatan nasional.

Jaminan kecelakaan kerja dan jaminan kematian diatur lebih jauh dalam Peraturan Pemerintah No. 44 Tahun 2005 Tentang Penyelenggaraan Program Jaminan Kecelakaan Kerja dan Jaminan Kematian. Ketentuan Pasal 1 Angka (1) dan (2) Peraturan Pemerintah No. 44 Tahun 2005 menyebutkan manfaat dari jaminan kecelakaan kerja dan kematian, Jaminan Kecelakaan Kerja yang selanjutnya disingkat JKK adalah manfaat berupa uang tunai dan/atau pelayanan kesehatan yang diberikan pada saat peserta mengalami kecelakaan kerja atau penyakit yang disebabkan oleh lingkungan kerja ${ }^{13}$. Jaminan Kematian yang selanjutnya disingkat JKM adalah manfaat uang tunai yang diberikan kepada ahli waris ketika peserta meninggal dunia bukan akibat kecelakaan kerja ${ }^{14}$. Manfaat jaminan Kecelakaan dijelaskan dalam Pasal 25 Peraturan Pemerintah No. 44 Tahun 2005.

Pasal 25:

(1) Peserta yang mengalami Kecelakaan Kerja atau penyakit akibat kerja berhak atas manfaat JKK.

(2) Manfaat JKK sebagaimana dimaksud pada ayat (1) berupa:

a) Pelayanan kesehatan sesuai kebutuhan medis yang meliputi:

1) Pemeriksaan dasar dan penunjang;

2) Perawatan tingkat pertama dan lanjutan;

\footnotetext{
12 Jimmy, Op. Cit. h. 238

13 Pasal 1 angka (1) Peraturan Pemerintah No. 44 Tahun 2005 Tentang Penyelenggaraan Program Jaminan Kecelakaan Kerja dan Jaminan Kematian

14 Pasal 1 angka (2) Peraturan Pemerintah No. 44 Tahun 2005 Tentang Penyelenggaraan Program Jaminan Kecelakaan Kerja dan Jaminan Kematian
} 
3) Rawat inap kelas i rumah sakit pemerintah, rumah sakit pemerintah daerah, atau rumah sakit swasta yang setara;

4) Perawatan intensif;

5) Penunjang diagnostik;

6) Pengobatan;

7) Pelayanan khusus;

8) Alat kesehatan dan implan;

9) Jasa dokter/medis;

10) Operasi;

11) Transfusi darah; dan/atau 1

12) Rehabilitasi medik.

b) Santunan berupa uang

1) Penggantian biaya pengangkutan Peserta yang mengalami Kecelakaan Kerja atau penyakit akibat kerja, ke rumah sakit dan/atau ke rumahnya, termasuk biaya pertolongan pertama pada kecelakaan;

2) Santunan sementara tidak mampu bekerja;

3) Santunan Cacat sebagian anatomis, Cacat sebagian fungsi, dan Cacat total tetap;

4) Santunan kematian dan biaya pemakaman;

5) Santunan berkala yang dibayarkan sekaligus apabila Peserta meninggal dunia atau Cacat total tetap akibat Kecelakaan Kerja atau penyakit akibat kerja;

6) Biaya rehabilitasi berupa penggantian alat bantu (orthose) dan/atau alat pengganti (prothese);

7) Penggantian biaya gigi tiruan; dan/atau

8) Beasiswa pendidikan anak bagi setiap Peserta yang meninggal dunia atau Cacat total tetap akibat kecelakaan kerja.

Di dalam Peraturan Pemerintah No. 44 Tahun 2005 ini sebenarnya sudah memberikan ruang yang cukup besar bagi mahasiswa mangang untuk dapat mengikuti jaminan sosial tenaga kerja. Khususnya Program jamian kecelakaan kerja dalam :

Pasal 28:

(1) Dalam hal magang, siswa kerja praktek, tenaga honorer, atau narapidana yang dipekerjakan pada Pemberi Kerja selain penyelenggara negara dalam proses asimilasi, apabila mengalami Kecelakaan Kerja, dianggap sebagai Pekerja dan berhak memperoleh manfaat JKK sesuai ketentuan dalam Pasal 25 ayat (2).

(2) Untuk menghitung besarnya manfaat JKK sebagaimana dimaksud pada ayat (1), maka magang atau siswa kerja praktek atau narapidana dianggap menerima Upah sebesar Upah terendah sebulan dari Pekerja yang melakukan pekerjaan yang sama pada Pemberi Kerja selain penyelenggara negara tempat yang bersangkutan bekerja atau dipekerjakan.

(3) Ketentuan mengenai tata cara pembayaran Iuran JKK bagi Peserta magang, siswa kerja praktek atau narapidana yang dipekerjakan pada Pemberi Kerja selain penyelenggara negara dalam proses asimilasi diatur dengan Peraturan Menteri berkoordinasi dengan instansi terkait.

Selain itu, proses pengikutsertaan mahasiswa magang untuk dapat mengikuti program jaminan sosial tenaga kerja, khususnya Program jaminan kecelakaan kerja telah diatur pembayaran iurannya secara mandiri (funded social security) sebesar Rp 6.800,00 
(enam ribu delapan ratus rupiah) setiap bulan ${ }^{15}$, dan proses pendaftarannya dapat dibuat kelompok secara sendiri maupun secara kolektif dengan mengisikan formulir pendaftaran di BPJS Ketenagakerjaan ${ }^{16}$, dan akan aktif saat nomor kepesertaannya sudah dikeluarkan oleh BPJS Ketenagakerjaan

\section{PE N U T P}

Kesimpulannya bahwa selama ini dalam proses pemangangan mahasiswa perguruan tinggi pada instansi pemerintah maupun perusahaan swasta jaminan sosial tenaga kerja tidak begitu diperhatikan sementara dalam sistem jaminan sosial tenaga kerja telah memberikan ruang yang cukup luas untuk dapat dimanfaatkan sebagai sarana perlindungan bagi mahasiswa magang. Hal ini terjadi karena belum adanya pemahaman yang baik terkait dengan konsep mahasiswa magang yang dapat diartikan sebagai pekerja, dan oleh karenanya mereka juga diberikan hak untuk mendapatkan perlindungan jaminan sosial tenaga kerja.

\section{DAFTAR PUSTAKA}

\section{Buku}

[1] Uwiyono, Aloysius. (2018), Asas - Asas Hukum Perburuhan, Jakarta: Rajawali Pers.

[2] Wijayanti, Asri. (2014), Hukum Ketenagakerjaan Pasca Reformasi, Cetakan ke 4, Jakarta: Sinar Grafika.

[3] Suwondo, Candra. (2004), Outsourcing, Implementasi Di Indonesia, Jakarta: Gramedia.

[4] Soepomo, Iman. (1985), Pengantar Hukum Perburuhan, Jakarta: Djambatan.

[5] Sembiring, Jimmy J. (2016), Hak dan Kewajiban pekerja Berdasarkan Peraturan Terbaru Cetakan Pertama, Jakarta: Visimedia.

\section{Jurnal dan Lain-Lain}

[6] Adillah, Siti Ummu dan Anik, Sri. (2015), Kebijakan Jaminan Sosial Tenaga Kerja Sektor Informal Berbasis Keadilan Sosial Untuk Meningkatkan Kesejahteraan, Yustisia. Vol. 4 No. 3.

[7] Kahfi, Ashabul. (2016), Perlindungan Hukum Terhadap Tenaga Kerja, Jurisprudentie, Volume 3 Nomor 2.

\footnotetext{
15 Pasal 20 ayat (3) Peraturan Pemerintah No. 44 Tahun 2005 Tentang Penyelenggaraan Program Jaminan Kecelakaan Kerja dan Jaminan Kematian

16 Pasal 11 ayat (3) Peraturan Pemerintah No. 44 Tahun 2005 Tentang Penyelenggaraan Program Jaminan Kecelakaan Kerja dan Jaminan Kematian
} 